\title{
REVISITED: TATAR CULTURAL HERITAGE IN BERLIN, GERMANY
}

\section{E. Tietmeyer}

\author{
Director of Museum Europäischer Kulturen \\ Berlin, Germany \\ e.tietmeyer@smb.spk-berlin.de
}

This article presents an overview of the Berlin Museum of European Cultures' $\left(\mathrm{MEK}^{1}\right)$ collaborative work concerning Kazan and Crimean Tatars and most of all of the Crimean Tatar collection of the Museum. This consists of more than 990 objects of everyday life, photographs, and paintings dating from the middle of the $19^{\text {th }}$ century up to today. Most of them were collected in the late 1920s by the Berlin researchers Nata and Hans Findeisen on the Crimean Peninsula and some of them by the Berlin journalist Gustav Küppers in the Dobrogea/Black See - Romania in the 1930s. Based on that, the author of the article collected objects that reflect cultural change and socio-political issues in the Crimea in the middle of the 1990s. Further the article pays special attention to the Berlin painter Wilhelm Kiesewetter. His works show foreign lifestyle which he witnessed during his 14 year journey across Northern Europe, Russia and West Asia. There he also visited Kazan, the capital of Tatarstan, but his two-year stay on the Crimean peninsula from 1845 to 1847 was the most emphatic and pleasant for Kiesewetter. Thus, he was very efficient in describing Crimean Tatar everyday life.

Keywords: Tatars, Berlin, Museum of European Cultures, painter Wilhelm Kiesewetter, cultural heritage.

For citation: Tietmeyer E. Revisited: Tatar cultural heritage in Berlin, Germany. Istoricheskaya etnologiya - Historical Ethnology, 2019, vol. 4, no. 1, pp. 85-92. DOI: $10.22378 /$ he.2019-4-1.85-92

\section{About the Museum and its activities}

The MEK is located in the Southwestern part of Berlin called Dahlem. (Fig. $1^{*}$ ) It is one of 15 National Museums in Berlin and a part of the Prussian Cultural Heritage Foundation. ${ }^{2}$ This Museum is relatively young, unlike the predecessor institutions from which it emerged. It was established in 1999 from

${ }^{1}$ MEK is the abbreviation of the German Museum's name "Museum Europäischer Kulturen".

* See Fig. 1-5 for the article on the color insert.

${ }^{2}$ Staatliche Museen zu Berlin - Stiftung Preußischer Kulturbesitz. See detailed information at www.smb.museum/mek (January 6, 2019). 
the consolidation of the Museum for (former German) Folklore (Museum für [Deutsche] Volkskunde) and the European Collection of the Museum of Ethnology (Museum für Völkerkunde resp. Ethnologisches Museum) in Berlin, both over 100 years old at that time. One reason for the merger was to remove the national self-restriction of the Museum of Folklore back then.

Meanwhile, with around 285,000 items, The MEK houses one of the greatest collections of European ethnography and cultural history from the 18th century up to the present day. The work is mainly related to everyday culture and living environments in Europe.

One of the Museum's profile lines is to ad dress the topic of cultural contacts in and with Europe. It thereby deals with current questions as to the forms and consequences of cultural diversity in European society. This is reflected in the permanent exhibition called "Cultural contacts. Living in Europe," which demonstrates that Europe is remarkable for a certain concord of cultures, despite its overall diversity and multiculturality. It can be explained by several reasons, one of which is the ever lasting mobile behaviour of people. On the one hand, it has brought about culture encounters and commonalities, leading to cultural changes and the development of hybrid global cultures and communities. On the other hand, it continually gives rise to questions about identity of individuals and groups in Europe, which try to express their ties to their homeland, sometimes even isolate themselves out of loss and uncertainty. The consequence of these apparently contradictory tendencies is cultural diversity within the unity of Europe. In the exhibition these topics are presented by examples that bring up new questions to old objects. ${ }^{3}$

Therefore, one of the tasks of the MEK is to draw attention to variety of culture in society, create respect for people from different cultures. Great importance is attributed to the inclusion of the characteristic views of a particular culture, respectively the people who feel that they belong to the corresponding culture - and this requires participative methods in each case.

With that in mind, the MEK started an event format to set up new cultural contacts in Berlin and Europe in 2000. It includes a series named "European Cultural Days" (Europäische Kulturtage): every year a region, a city, a country or an ethnic group is presented on a specific topic. The Cultural Days last for several weeks, consist of a small exhibition and an extensive events programme. The curators of the MEK provide a platform for the self-presentation of others and coordinate everything on site. The characteristic feature of the Cultural Days is the collaboration with the corresponding partner museums in the respective European country, and/or with the embassies, cultural organisations, associations or communities in Berlin. Due to the multifarious collaboration during the Cultural Days it is, in particular, the Berliners of non-German origin the MEK is addressing, who will visit the museum as the new clientele and come

${ }^{3}$ See Tietmeyer, Elisabeth and Ziehe, Irene (eds.). 2011. Cultural Contacts. Living in Europe. Leipzig: Seemann und Henschel Verlag. 
into contact with the regular visitors who are predominantly German. ${ }^{4}$ An example for this were the so-called Tatar Cultural Days which have been celebrated in cooperation with the Tatar-Bashkir Cultural Association ${ }^{5}$ in Berlin 2003. They consisted of a small exhibition of paintings made by Tatar artists, and many musical events, textile workshops, lectures for example about the history of the Volga Tatars. All of this was organized and conducted by the above mentioned association, whereas MEK's functioned as a "facility manager." The visitors were thrilled since they have never arranged activities of that kind in a museum. ${ }^{6}$ (Fig. 2)

\section{Ethnographic collection, photographs, and images of the Crimean Tatars at the MEK}

Compared to the lack of items representing Tatarstan in the MEK collection, the Museum houses around 500 cultural historical items of the Crimean Tatars presenting aspects of their past and recent life worlds. for the same concerns approxomately 490 photographs on different topics, ranging from albumin prints of the early 20th century up to the digital photos from recent time. The origin of many, mostly early photos is (still) unclear, others were taken by the above mentioned Nata Findeisen and by the author. From an ethnological external perspective, they show everyday and festive culture, the appearance of people, the natural and comfortable environment of the Crimean Tatars.

The largest and most significant collection of Crimean Tatar items was arranged by Hans and Nata Findeisen. In 1929, the ethnographer Hans Findeisen had an opportunity to go to a collective trip from the Berlin Museum of Ethnology to Crimea and the Caucasus region. His aim complied with the thematic focus of the general ethnographical museum approach at the time. He felt obliged to carry out so-called "rescue" work before the traditional culture items would undergo transformation or would have been destroyed. While Hans Findeisen gathered items in the Caucasus region, it was his wife Nata who looked for the Crimean Tatar ethnographic art, which she wanted to collect and

${ }^{4}$ See also Tietmeyer, Elisabeth. 2006. “'Fremd ist der Fremde nur in der Fremde'. Das Museum Europäischer Kulturen als Ort interkultureller Begegnungen”, Jahrbuch Preußischer Kulturbesitz, 43, pp. 269-281.

5 Tatarisch-baschkirischer Kulturverein e.V.: https://www.netzkraft.net/profil. php?teilnehmer=2046\&lg=de (January 6, 2019).

${ }^{6}$ Kharissov, Ildar and Tietmeyer, Elisabeth. 2004. "Tatarische Kulturtage im Museum Europäischer Kulturen - Staatliche Museen zu Berlin vom 30.8. bis zum 14.9.2003", in: Binder, Beate and Deuber-Mankowsky, Astrid. Die Botschaft der Botschaften. (=Berliner Blätter. Ethnographische und ethnologische Beiträge, 33), pp.100-102.

${ }^{7}$ The following text has already been published in a similar form, see Tietmeyer, Elisabeth. (2017). "Material Culture and Identity. On the history and ethnography of the Crimean Tatars in the Museum Europäischer Kulturen - Staatliche Museen zu Berlin". Crimean Historical Review, 1, pp. 169-191. 
document with photographs in the former capital Bakhchysarai and in the vicinity. During her stay, she cooperated closely with Hussein Bodaninsky, who at the time was the director of the ethnographic museum in the Khan's Palace of Bakhchysarai. Nata clearly oriented her acquisitions to those in the Palace $\mathrm{Mu}-$ seum. She devoted herself intensely during her field stay to the Khan palace, but mainly to the city of Bakhchysarai (Fig. 3), the local range of handicraft areas and the appearance, such as the everyday lives of people. She visited a small nearby village where she had the opportunity to attend a wedding that she later described in a publication. The 450 items that were collected include the following: tools and products made by various craftsmen such as jewellers, wood turners, and shoemakers; agricultural tools, household items, handicrafts, richly ornamented garments for men, women and children; weapons, musical instruments, a few items related to cult or of religious nature.

28 Crimean rural items have their origin in the Romanian Dobrogea, one of several exile regions in which the Crimean Tatars, who had fled from the Crimea in the $18^{\text {th }}$ and $19^{\text {th }}$ century, had partially preserved their culture. This is clearly shown in objects of everyday life which were acquired by the journalist and photographer Gustav Adolf Küppers in 1936 and 1937. On behalf of the Berlin Museum of Ethnology, he undertook a total of five collection trips between 1935 to 1938 to Southeast and East Europe, especially Romania.

Starting with the historical collection of Crimean Tatar items and the fate of the Crimean Tatars after 1944, the author was puzzled by the question of its impact on their material culture. ${ }^{8}$ Thus in 1994 she conducted a field research at the Crimea about everyday live and to get some information concerning the stored historical objects. Moreover, she managed to successfully bring 20 contemporary Crimean Tatar ethnographic objects from Crimea. They include, flat fabrics, such as typical kilims worn by Crimean Tatar women in Uzbek exile in the 1960s, which were made using a traditional template. Other items, such as traditional women's headpieces, were made in the Crimea, albeit simply and poorly reproduced, because the Crimean Tatars barely knew the old handicraft techniques in the early 1990s. However, they wanted to explore their vanished culture again, examples of that are now presented in the Museum collection.

\section{Wilhelm Kiesewetter}

One of the most interesting collections concerning the Crimean Tatar culture consist of 34 oil paintings and 3 house and settlement models that show a stranger's perspective on the Crimean Tatars in the middle of 19th century. They belong to a collection of 163 oil paintings on canvas or cardboard and 12 carved and painted models made by the Berlin artist Wilhelm Kiesewetter (1811-1865). The works show foreign lifestyles, which he met during his two journeys lasting all in all 14 years through North and East Europe and West

${ }^{8}$ I was responsible for the European Department of the Museum of Ethnology from 1993 to 1999 before it merged with the Museum of Folklore to the MEK. 
Asia. He wanted to present his art to his contemporaries as well as to the posterity, not least by means of his publications. He passed wide parts of Russia and also visited Kazan where he painted at least two Tatar men (Fig. 4), but did not write anything about Tatarstan in his diary - only concerning his first travelling route. $^{9}$

During the two-year stay from 1845 to 1847 on the Crimean peninsula, Kiesewetter visited the cities of Simferopol and Bakhchysarai, as well as Sudak, Alushta, Gurzuf, Yalta, and Sevastopol on the south coast. Apparently, he got accustomed to the Tatar community and adapted his behaviour to the local lifestyle so well that the Tatars started calling him using a Tatar name Abdullah and honored him with the title "Aga."

In his published diary Kiesewetter describes his observations on the Crimean Tatars in five essays. ${ }^{10}$ His first essay about the Crimean inhabitants, called "Tatar wedding festivities ...". gives a brief overview of the Crimean Tatars' lifestyle and closely examines the process of a wedding feast with the "Gypsies" music and the role he played there. In his second essay, which is called "The bazaar and a harem in Bakhchysarai ...", Kiesewetter describes the Khan capital, its bazaar district with many different craftsmen and coffee houses. The third essay deals with the "Palace of the last Tatar khans in Bakhchysarai", which he explains at great length just as if he is painting it. The MEK holds 9 oil paintings from the palace, and the most impressive item is the model of the palace. The two other models represent a Tatar coffee house and a settlement of the Gurzuf village on the southern coast of the Crimea. In his last two essays Kiesewetter describes again what interested him most: the everyday life and the lifestyle of the people he visited (Fig. 5). Their lives can be understood only on the background of their environment, which Kiesewetter describes explicitly in the chapter called "Tatars on the southern coast of the Crimea". Most of the time he spent in Gurzuf to make the model and some pictures. Here he explains, for instance, a typical design on the south coast and how houses are used by their inhabitants. ${ }^{11}$

${ }^{9}$ See Kiesewetter, (August) Wilhelm. 1850. Förklaring öfver Modeller, Oljetaflor och Skizzer uti Konstkabinettet, på en mångårig vandring i Orienten. (Exhibition catalogue). Lund: author's edition. ---. 1854 a. Kiesewetters ethnographische Reisebilder. Berlin: author's edition. 1854 b. Mittheilungen. p. 100.

${ }^{10}$ The review of Kiesewetter's essays has been already published, see Tietmeyer, Elisabeth. (2017). "Material Culture and Identity. On the history and ethnography of the Crimean Tatars in the Museum Europäischer Kulturen - Staatliche Museen zu Berlin". Crimean Historical Review, 1, pp. 169-191.

${ }^{11}$ Kiesewetter, Wilhelm. 1854b. Mittheilungen, pp. 63-100. 


\section{MEK's tasks: "The past for the future"}

The description of the MEK's Tatar collections evokes the question of what the Museum intends to do with it:

Crimean Tatars are looking for their cultural identity more than ever and focus mainly on a past life. In the 1990s, many museums were newly opened at the peninsula, enriched with the items which the Crimean Tatars have brought from exile. Before they or their descendants returned from the countries to which they have been deported, they had preserved, idealized and handed down their culture in a foreign environment. They did not only want to recall their past but they also aimed to revitalize it. They have used the historical material culture as a link to this day and believed they must reproduce it to show and share their ethnic identity. Despite of the fact that there were Crimean Tatar art and cultural heritage museums in Crimea, since the last 20 years Crimean Tatar artists, scientists and politicians have been visiting the MEK in Berlin again and again, because here they were able to find items which were no longer available in Crimea. Many representatives of ethnic groups in Europe or Eastern European countries, whose ancestors had once been painted by Kiesewetter, come to visit the MEK to see the artist's contextualized and annotated images and models. The museum attendees include not only Tatars from Crimea and Tatarstan, but also Kalmyks from Russia, Sámi from Scandinavia, and Armenians. They show particular interest in the oil paintings and models that help them get an overall perspective of their ancestors's life and their past culture. Kiesewetter's works and the accompanying publications help these people find their identities, however, in this context the issue is whether or not they are aware of the fact that the artist used his artistic freedom and imagination. This is supported by MEK's special exhibitions about Kiesewetter's work. ${ }^{12}$

Another highlight of the meeting with the Crimean Tatars was a project initiated and financed by the German Goethe-Institut in Ukraine according to which Tatars were supposed to receive the authentic digital copies of the images and models made by Kiesewetter during his work in the Crimean peninsula area. In May 2005, the Goethe-Institut and the MEK handed over the copies to the Crimean Ministry of Culture with the purpose to exhibit them at various museums in Ukraine. Besides, a relevant publication was published in German and Russian languages. It includes all paintings and models of the Crimean Tatars and Crimean Gypsies, provides annotations of the original quotes from Kiesewetter's publications. Moreover, an introductory article about the artist was written by me and his five aforementioned essays were printed. ${ }^{13}$

${ }^{12}$ Like "Explorations in Europe: Visual Studies in the 19. Century", 2011/12.

${ }^{13}$ Kaulbach, Barbara and Tietmeyer, Elisabeth (eds.). 2005. Der Maler und Ethnograph Wilhelm Kiesewetter (1811-1865) auf der Krim. Kiev: Goethe-Institut Ukraine, author's edition. (German/Russian). 
Meanwhile, many Tatar artists have been engaged in their cultural past and are trying to revitalise and develop it, by promoting Crimean Tatar handicrafts, for instance. The MEK cooperated with some of them and acquired artefacts. There still is scientific interest in analysing the MEK's collection of Crimean Tatar objects and the perspectives on the Tatar culture in the past and present. The task of the Museum is to draw attention to all these developments by supporting these initiatives and by offering them a platform for research.

\section{REFERENCES}

1. Tietmeyer, Elisabeth and Ziehe, Irene (eds.). 2011. Cultural Contacts. Living in Europe. Leipzig: Seemann und Henschel Verlag.

2. Tietmeyer, Elisabeth. 2006. "'Fremd ist der Fremde nur in der Fremde'. Das Museum Europäischer Kulturen als Ort interkultureller Begegnungen", Jahrbuch Preußischer Kulturbesitz, 43, pp. 269-281.

3. Tatarisch-baschkirischer Kulturverein e.V.: URL: https://www.netzkraft.net /profil.php?teilnehmer=2046\&lg=de (January 6, 2019).

4. Kharissov, Ildar and Tietmeyer, Elisabeth. 2004. "Tatarische Kulturtage im Museum Europäischer Kulturen - Staatliche Museen zu Berlin vom 30.8. bis zum 14.9.2003", in: Binder, Beate and Deuber-Mankowsky, Astrid. Die Botschaft der Botschaften. (=Berliner Blätter. Ethnographische und ethnologische Beiträge, 33), pp.100-102.

5. Tietmeyer, Elisabeth. (2017). "Material Culture and Identity. On the history and ethnography of the Crimean Tatars in the Museum Europäischer Kulturen - Staatliche Museen zu Berlin". Crimean Historical Review, 1, pp. 169-191.

6. Kiesewetter, (August) Wilhelm. 1850. Förklaring öfver Modeller, Oljetaflor och Skizzer uti Konstkabinettet, på en mångårig vandring i Orienten. (Exhibition catalogue). Lund: author's edition. 1854 a. Kiesewetters ethnographische Reisebilder. Berlin: author's edition. 1854 b. Mittheilungen. p. 100.

7. Kiesewetter, Wilhelm. 1854b. Mittheilungen, pp. 63-100.

About the author: Prof. Dr. Elisabeth Tietmeyer is a Director of Museum Europäischer Kulturen (Im Winkel 8, D-14195 Berlin, Germany); e.tietmeyer@smb.spkberlin.de 


\section{К ВОПРОСУ О КУЛЬТУРНОМ НАСЛЕДИИ ТАТАР В БЕРЛИНЕ, ГЕРМАНИЯ}

\section{Элизабет Титмайер}

Музей Европейских Культур

Берлин, Германия

e.tietmeyer@smb.spk-berlin.de

В статье представлен обзор совместной работы Берлинского Музея европейских культур (МЕК), касающейся казанских и крымских татар и большей части крымскотатарской коллекции учреждения. Коллекция состоит из более чем 990 предметов повседневной жизни, фотографий и картин, датирующихся с середины XIX века до наших дней. Большинство из них были собраны в конце 1920-х годов берлинскими исследователями Натой и Хансом Финдейзеном на Крымском полуострове, другая часть - берлинским журналистом Густавом Кюпперсом в Добрудже / Черном Престоле - в Румынии в 1930-х годах. Исходя из этого, автор статьи собрала объекты, отражающие культурные изменения и социально-политические проблемы в Крыму в середине 1990-х годов. Особое внимание уделяется берлинскому художнику Вильгельму Кизеветтеру, чьи работы демонстрируют образ жизни за рубежом, в атмосферу которого он имел возможность окунуться во время своего 14-летнего путешествия по Северной Европе, России и Западной Азии. Он также посетил Казань, столицу Татарстана, но его двухлетнее пребывание на Крымском полуострове с 1845 по 1847 гг. стало наиболее ярким и запоминающимся событием для художника. Он очень подробно описал повседневную жизнь крымскотатарского народа.

Ключевые слова: Татары, Берлин, Музей европейских культур, художник Вильгельм Кизеветтер, культурное наследие.

Для цитирования: Tietmeyer E. Revisited: Tatar cultural heritage in Berlin, Germany // Историческая этнология. 2019. Т. 4, № 1. С. 85-92. DOI: 10.22378/he.2019-4-1.85-92

Сведения об авторе: Элизабет Титмайер - профессор, директор Музея европейских культур (Im Winkel 8, D-14195 Berlin, Germany); e.tietmeyer@smb.spkberlin.de 


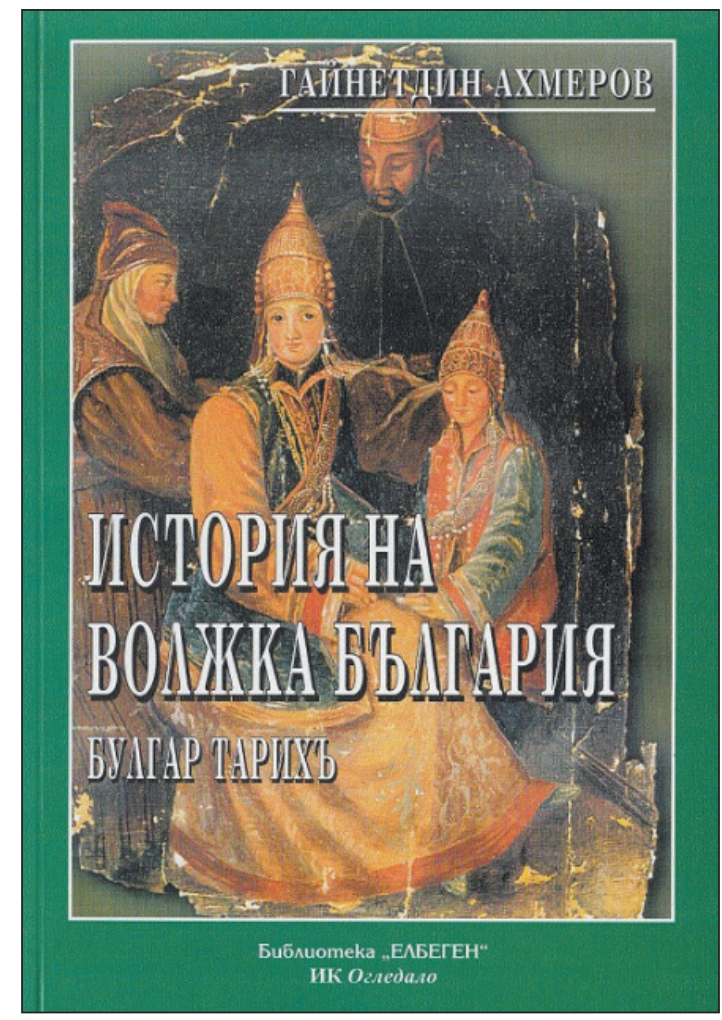

К статье: Станчев Е. Гайнетдин Ахмаров в контексте интерпретирования Волжской Булгарии в современной болгарской историографии

Puc. 1. Обложка болгарского издания «История Булгарии» Г.Н. Ахмарова (опубликовано в 2002 г. в издательстве «Огледало», София, Болгария)

К статье: Tietmeyer E. Revisited: Tatar Cultural Heritage in Berlin, Germany

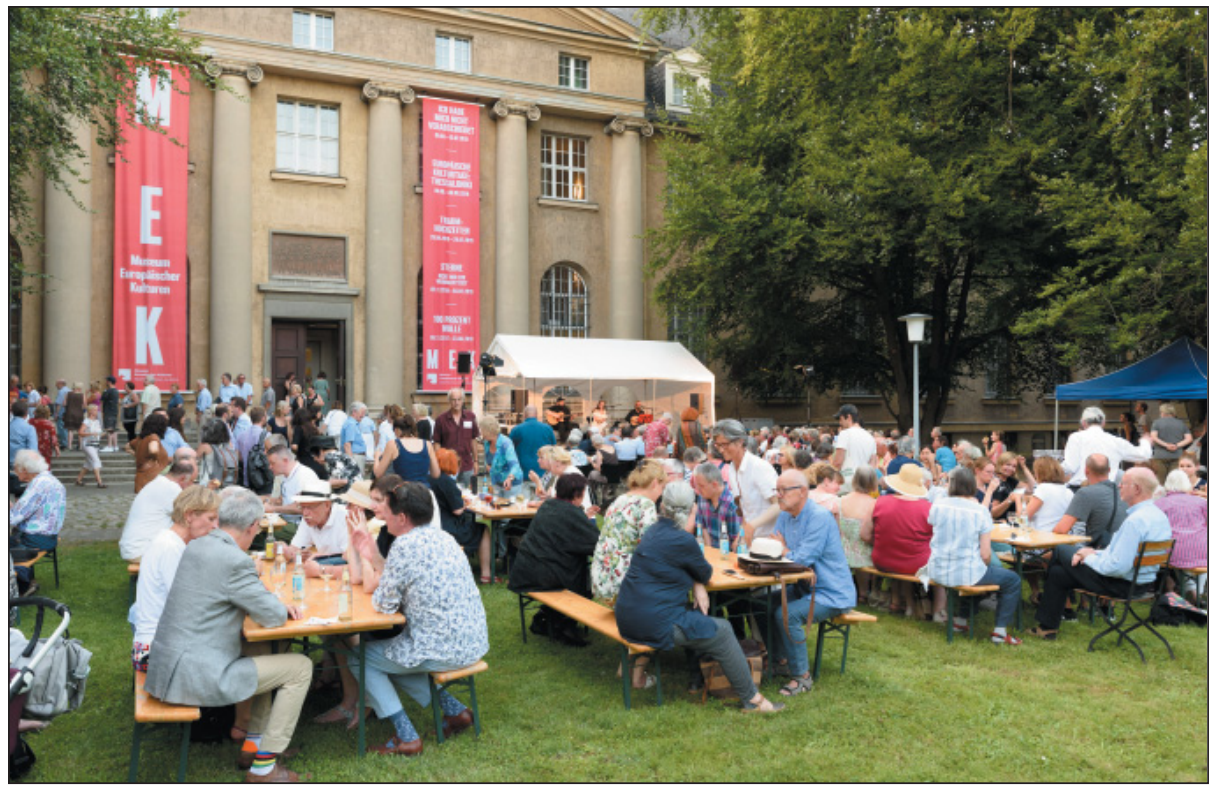

Fig. 1. Location of the Museum of European Cultures, Arnimallee 25, 14195 Berlin-Dahlem

(C) Staatliche Museen zu Berlin, Museum Europäischer Kulturen/Ute Franz-Scarciglia 


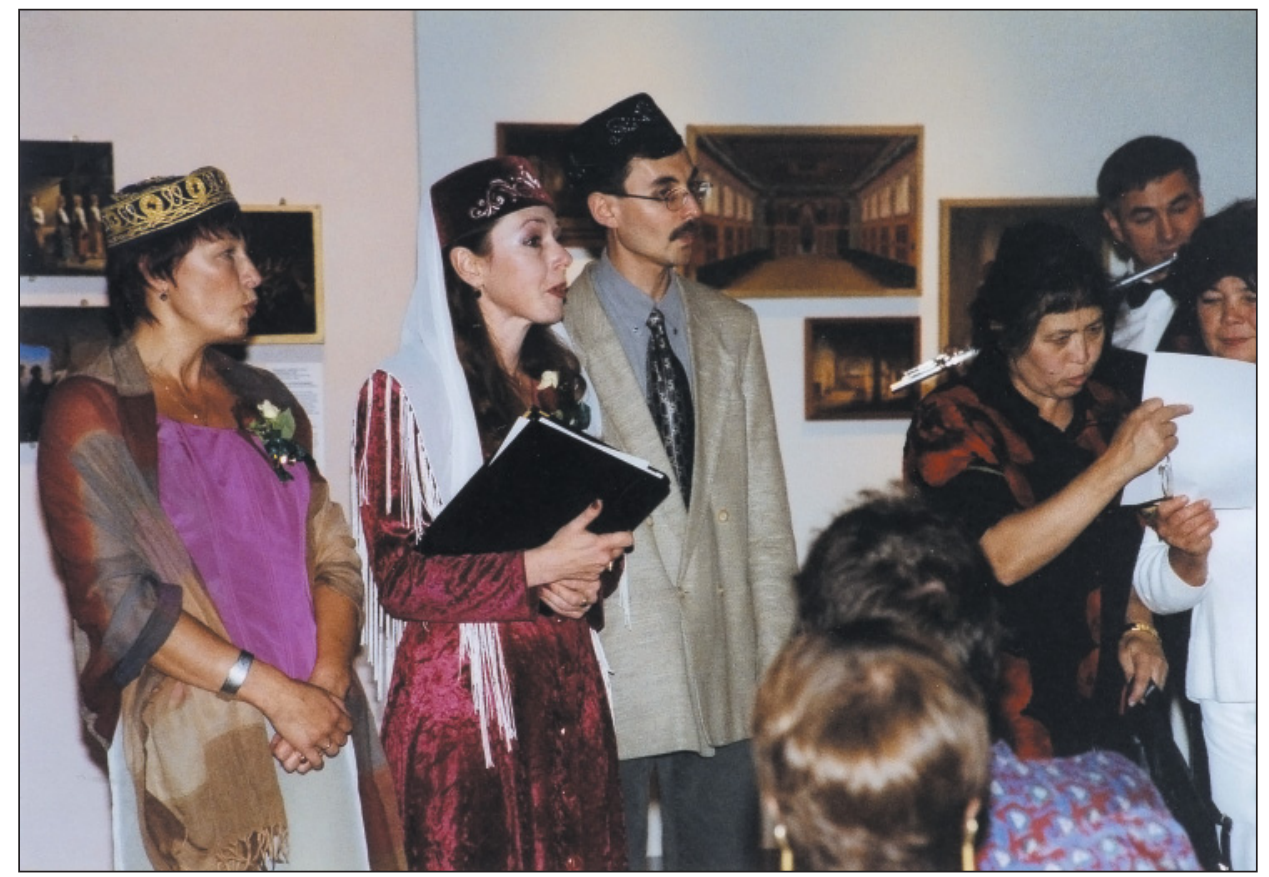

Fig. 2. Opening ceremony of the Tatar Cultural Days, September 2003 (C) Staatliche Museen zu Berlin, Museum Europäischer Kulturen/Ute Franz-Scarciglia

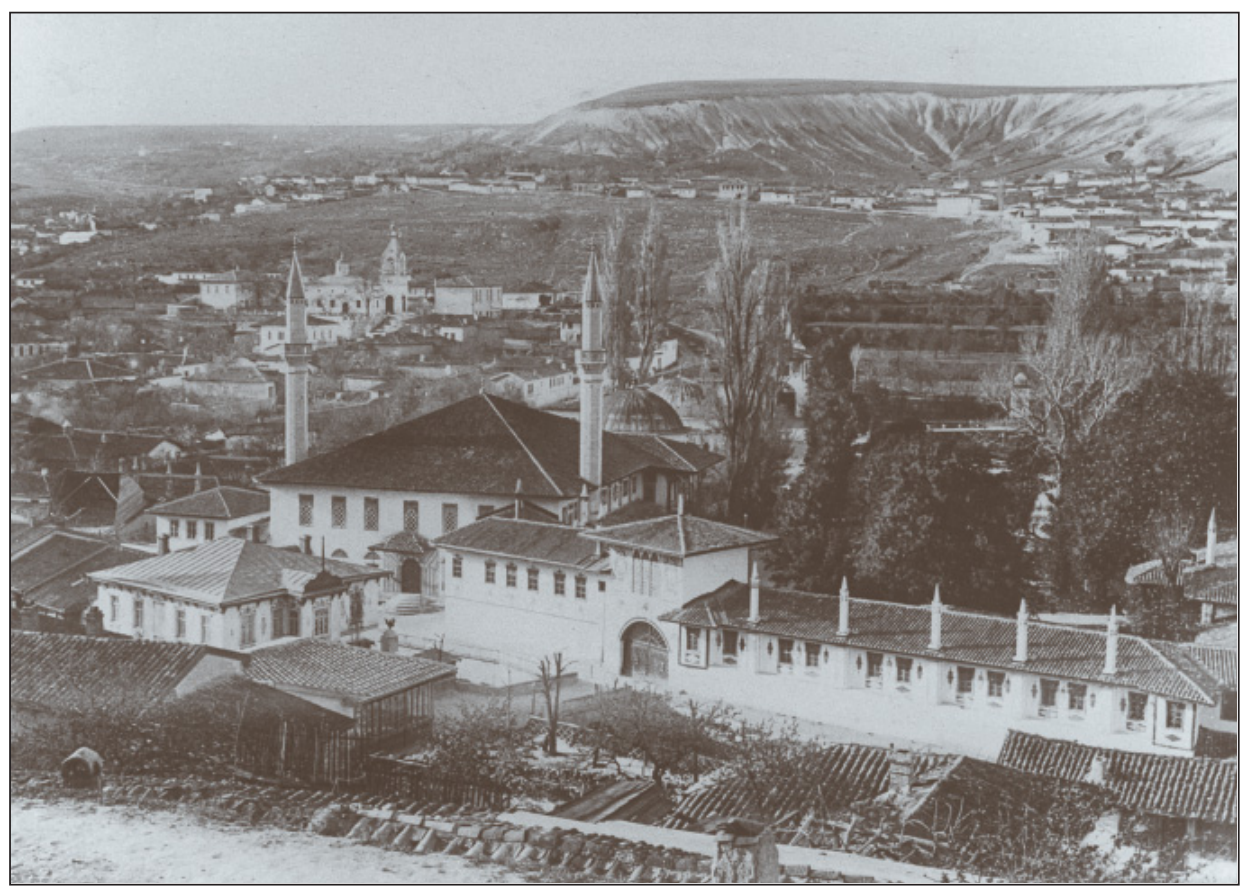

Fig. 3. Photograph of the Chan's Palace in Bakhchysarai, 1925

(C) Staatliche Museen zu Berlin, Museum Europäischer Kulturen/Nata Findeisen 


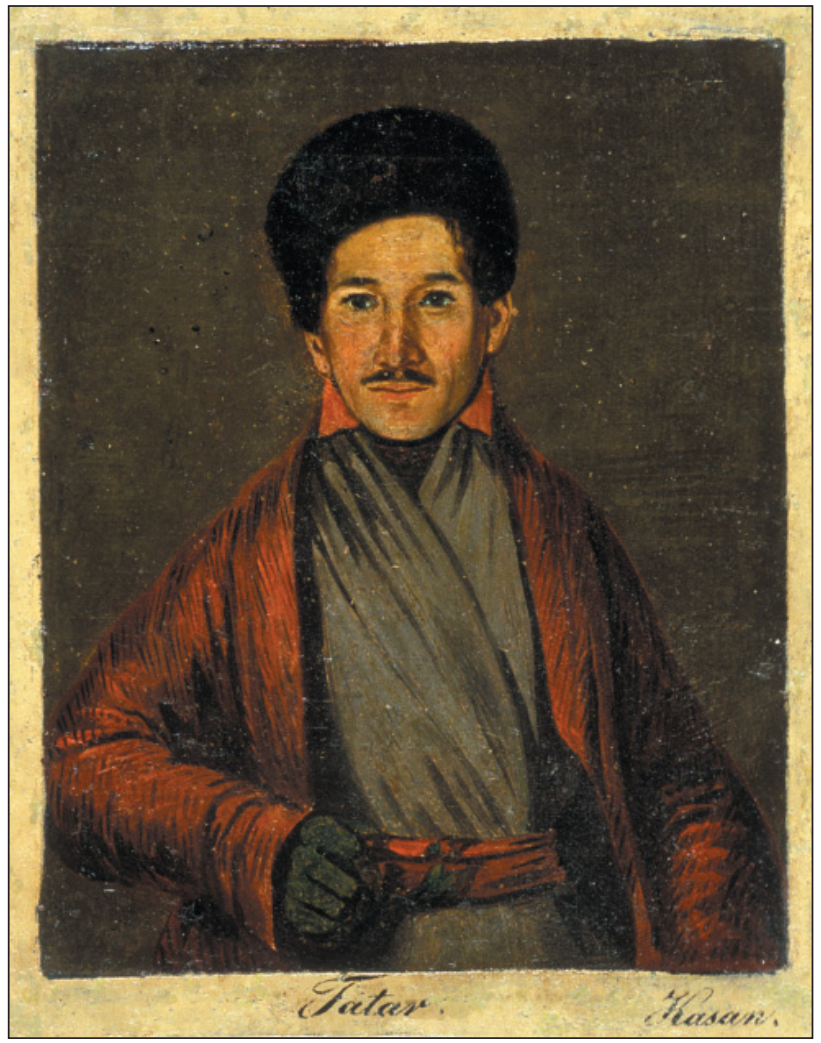

Fig. 4. Wilhelm Kiesewetter: "Tatar. Kasan."

$(18,4 \times 15,4 \mathrm{~cm}), 1842$

(C) Staatliche Museen zu

Berlin, Museum Europäischer Kulturen/Ute Franz-Scarciglia

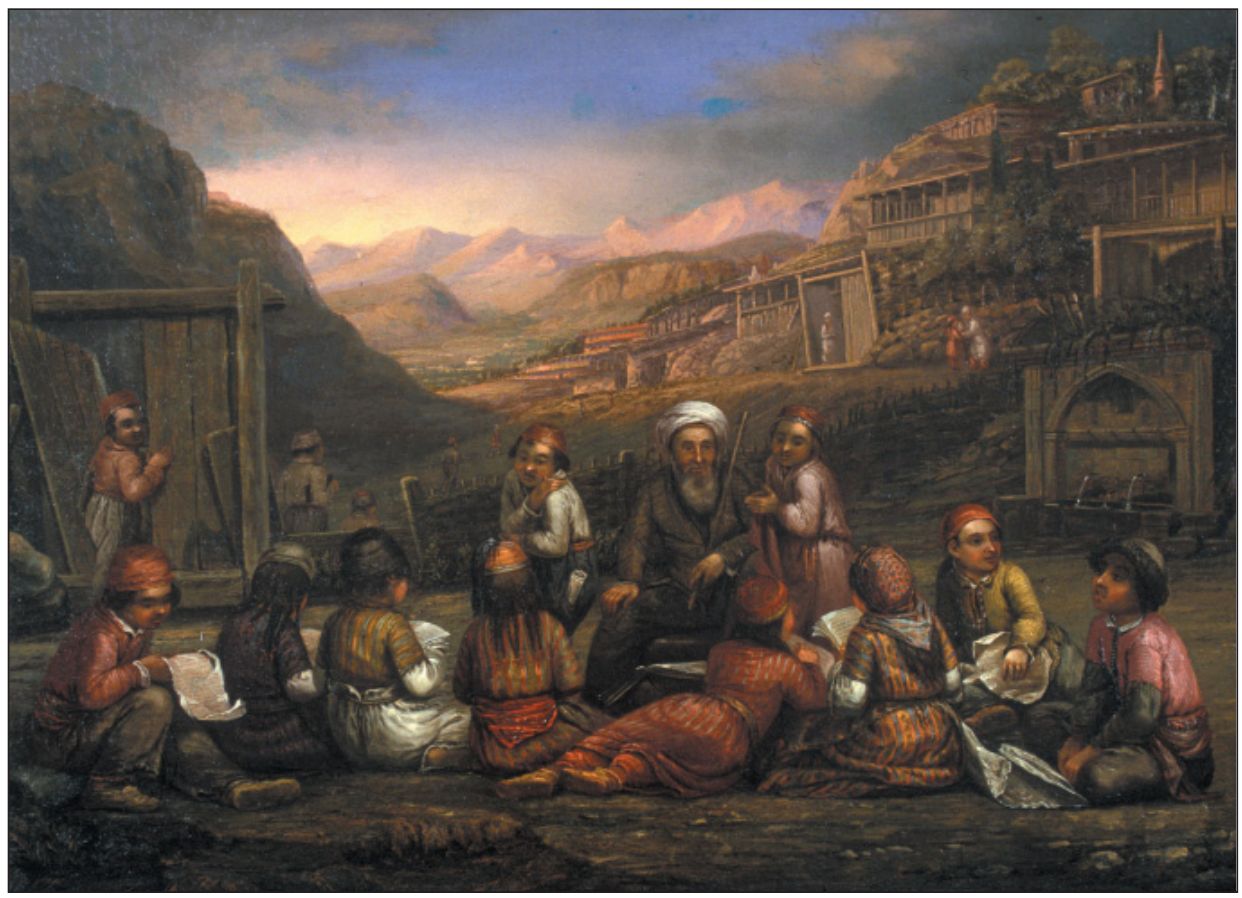

Fig. 5. Wilhelm Kiesewetter: "Tatar village school in the Crimea" (39.8 x $54 \mathrm{~cm})$ (C) Staatliche Museen zu Berlin, Museum Europäischer Kulturen/Ute Franz-Scarciglia 